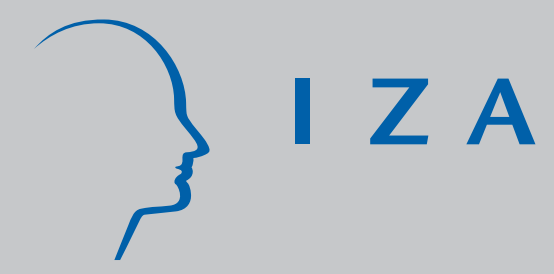

IZADP No. 1812

High Performance Workplaces and Family Friendly Practices: Promises Made and Promises Kept

J ohn S. Heywood

W.S. Siebert

Xiangdong Wei

October 2005 


\title{
High Performance Workplaces and Family Friendly Practices: Promises Made and Promises Kept
}

\author{
John S. Heywood \\ University of Wisconsin \\ W.S. Siebert \\ University of Birmingham Business School \\ and IZA Bonn \\ Xiangdong Wei \\ Lingnan University, Hong Kong
}

\author{
Discussion Paper No. 1812 \\ October 2005
}

\author{
IZA \\ P.O. Box 7240 \\ 53072 Bonn \\ Germany \\ Phone: +49-228-3894-0 \\ Fax: +49-228-3894-180 \\ Email: iza@iza.org
}

\begin{abstract}
Any opinions expressed here are those of the author(s) and not those of the institute. Research disseminated by IZA may include views on policy, but the institute itself takes no institutional policy positions.

The Institute for the Study of Labor (IZA) in Bonn is a local and virtual international research center and a place of communication between science, politics and business. IZA is an independent nonprofit company supported by Deutsche Post World Net. The center is associated with the University of Bonn and offers a stimulating research environment through its research networks, research support, and visitors and doctoral programs. IZA engages in (i) original and internationally competitive research in all fields of labor economics, (ii) development of policy concepts, and (iii) dissemination of research results and concepts to the interested public.
\end{abstract}

IZA Discussion Papers often represent preliminary work and are circulated to encourage discussion. Citation of such a paper should account for its provisional character. A revised version may be available directly from the author. 


\section{ABSTRACT \\ High Performance Workplaces and Family Friendly Practices: Promises Made and Promises Kept}

High performance workplaces elicit greater involvement and productivity from employees but past theory and evidence remain divided on whether or not such workplaces are compatible with family friendly work practices. We present new evidence on the association using perceptions of a representative sample of workers and an innovative testing framework. The evidence reveals that high performance workplaces are no more likely to make commitments to provide family friendly workplaces than are other workplaces. It shows, however, that high performance workplaces are more likely to keep the family friendly commitments they make, thereby maintaining a "psychological contract" based on mutual obligation. As providing family friendly practices requires both making and keeping commitments, the evidence confirms that high performance workplaces are more likely to provide such practices.

JEL Classification: J31, J32, J81

Keywords: high performance workplaces, family friendly practices, motivation, work incentives

Corresponding author:

W. S. Siebert

Business School

University of Birmingham

Edgbaston

Birmingham B15 2TT

United Kingdom

Email: w.s.siebert@bham.ac.uk

\footnotetext{
* The authors acknowledge the Department of Trade and Industry, the Economic and Social Research Council, the Advisory, Conciliation and Arbitration Service and the Policy Studies Institute as the originators of the Working in Britain in the Year 2000 Survey data, and The Data Archive at the University of Essex as the distributor of the data. None of these organizations bears any responsibility for the authors' analysis and interpretation of the data. The authors also thank Robert Drago for helpful comments on earlier drafts.
} 


\section{High Performance Workplaces and Family Friendly Practices: Promises Made and Promises Kept}

\section{Introduction}

A substantial body of research focuses on the "spillover" from the work environment to family

life. While it seems well recognized that the nature of jobs and the workplace influences the ability of workers to balance the demands of family and work, researchers hotly debate the nature of that influence. This debate becomes most heated when considering the role played by high performance management. On the one hand, participating in high performance workplaces (HPWs) may give people a greater sense of control and effectiveness that carries over to their ability to manage their family responsibilities. Moreover, the skills developed in HPWs may allow better management of family responsibilities. Osterman (1995) goes further, arguing that family friendly practices are part of the toolbox used by HPWs to elicit the needed commitment to encourage workers to participate and work hard within the firm. On the other hand, the worker commitment required by HPWs may crowd out the time and energy to undertake needed family responsibilities. HPWs obtain greater discretionary effort from employees by creating a time squeeze with negative job to home spillovers.

In the next section of this paper, we review a growing literature on the association between HPWs, family friendly practices and work family balance. The review highlights the rather mixed state of past results and allows us to set-up our own hypotheses. We examine 
worker perceptions with regard to two closely related issues. First, we investigate whether workers at HPWs are more or less likely to view their workplace as making a promise (implicit or explicit) to provide family friendly work practices. Second, we investigate whether workers at HPWs are more or less likely to view their workplaces as keeping these promises, if they made them in the first place. Our emphasis on keeping promises ties in with the literature on the "psychological contract", which views the HPW as motivating by shared perceptions of mutual obligation (Marsden, 2004) rather than simply by traditional incentives. We undertake our estimations with the recognition that an important indicator of family balance, the ability to spend desired time supporting one's family, varies with the promises made and kept about providing family friendly practices. Those workplaces that make but fail to keep promises have the lowest share of employees indicating balance, a share far below even those workplaces perceived as never making a promise in the first place. This indicates the importance of not simply undertaking surveys of management that indicate whether or not specific practices are available but instead examining worker's perceptions of whether or not the available practices are meaningful, encouraged and effective.

Our results from a representative sample of employees in the United Kingdom indicate that HPWs are no more likely than other workplace to make promises to provide family friendly practices. In short, there is no support for either the idea that such promises are an important 
part of attracting workers or the view that they are antithetical to having employees highly committed to their workplace. Yet, having said this we confirm our fundamental hypothesis that HPWs are significantly more likely to keep their promises regarding family friendly practices than are other workplaces. Thus, the common view that keeping promises represents a strong form of commitment indeed defines HPWs, just as argued by Walton (1985) in his classic article on “commitment” versus “control” management.

We also estimate the extent to which employees feel their employer's kept a promise of family friendly practices assuming they made one in the first place. These results indicate that HPWs rank higher on a five point scale of how well the promise was kept holding constant other important determinants. Since offering family friendly practices, requires both making and keeping the promise of providing them, the results imply a positive connection between HPWs and such practices. We confirm this connection directly by estimating a positive influence of HPWs on the probability of a workplace both making and keeping a promise to provide family friendly practices.

In what follows, section 2 describes past research emphasizing the importance of time available to meet family responsibilities as an indicator of family friendly work practices. It also presents our fundamental testing questions and hypotheses. Section 3 presents our methodology and data. Section 4 presents the results while a final section draws conclusions 
and suggests further lines of inquiry.

\section{Theory and Evidence on High Performance Workplaces and Family Friendly Practices}

In this section, we first set the stage by describing the increasing concern on the part of policy

makers and researchers over the extent of family friendly practices by employers. We

emphasize that the concern has been largely one over the available time workers have to fulfill

home and family responsibilities. Making this point clear helps establish our empirical

examination of family friendly practices that also focuses on the critical issue of employers

providing time for family responsibilities. The second portion of this section introduces the

debate over the relationship between HPWs and family friendly practices and reviews the

empirical literature to date. The final section identifies the theoretical underpinnings of our

investigation and the specific research hypotheses.

The Time Squeeze and Work-Family Balance

A series of inter-related changes have fueled increasing concern over the extent of family

friendly practices by employers. Primary among these has been the view that adult family

members find themselves in a time squeeze facing growing time commitments to work and

consequently unable to fulfill their responsibilities at home. Certainly, basic indicators of

labour force participation in the UK provide support for this view. The ten-year period ending in 
spring of 2004 saw a 12 percentage point increase in the lone parent employment rate to 54

percent and an 8 percentage point increase in share of couples with dependent children where both partners work to 68 percent (Walling 2005). Thus, of the 7.3 million working-age families with dependent children, less than 36 percent have a non-working parental caregiver. Moreover, these numbers represent a selected sample of those families that have chosen to have children. Rising female labor supply has apparently substituted for child rearing, not facilitated it (Castles 2003). Indeed, UK survey data shows that the proportion of working age women who are mothers continues to decline dramatically (MacInnes 2005). This and similar data from other European countries has given rise to a debate over whether or not increased family friendly work practices are needed to reduce dramatically failing fertility rates (Palomba 2003).

While labor force participation trends seem consistent with a parental time squeeze, evidence on a second source of concern, the "long-hours culture," seems less compelling. The government claims that the hours demanded by employers are incompatible with responsibility for a family and that "Britain's long hours working culture is bad for men, women and families... (Equal Opportunities Commission 2004)." Similarly, academic studies decry work intensification, lengthening working hours and inflexible work schedules as making workers less able to fulfill family responsibilities (Green 2001, Benyon et al. 2002, Dex 2003). Yet, there remains little or no compelling evidence that average UK working hours are actually increasing 
(Bosch 1999; Evans et al. 2001). As a consequence, concern over work intensification has focused on the inordinate number of workers working long hours even if the average number of hours has not changed greatly (Green 2001). Drago et al. (2005) go the next step to examine why workers persist in long hours (more than fifty per week) concluding that while a desire to purchase additional goods and workplace norms each play roles, fear of job loss does not play a role. In short, long hours my well be motivated by worker desire and choice not firm pressure. Moreover, a primary factor in driving family responsibilities, the number of children, continues to decline with family size falling and the number of dependent children in Britain at record lows (MacInnes 2005). Finally, MacInnes (2005) makes estimates using survey data that those who desire less work time (and correspondingly less pay) are, in fact, not those with family responsibilities. Women are less likely than men to want reduced hours. Single parents are less likely than others to want reduced hours. Mothers with dependent children at home are less likely to want reduced hours than are women without dependent children. MacInnes finds that two factors help explain why workers with children are less likely to want reduced hours. First, the labor force participation of women and their hours of work once in the labour force already adjust for the presence of children. Both the female participation rate and the average hours of working women drop as children are born and then increase as children grow older. Second, children are expensive and many workers do not want reduced hours and earnings during this 
critical time of family formation. ${ }^{1}$

In the end, it is not critical for our study whether or not work has intensified or hours have grown longer. Instead, it is important to recognize that whether or not workers have the time to fulfill family responsibilities has been a crucial metric for measuring work family balance. Recognizing this brings us to the third source of concern that the nature of work has changed making workers less able to fulfill their family responsibilities. This remains, in part, a concern about the quantity of time devoted to work but is also a concern about the energy, effort and submersion in work that modern organizations require.

High Performance Workplaces and Work Family Balance

While the exact terminology remains fluid, a number of researchers have chronicled a change toward a reorganized workplace with greater worker participation in decision-making and greater commitment. $^{2}$ Proponents of HPWs generally perceived them as beneficial for both employers and employees. Through a combination of work organization and human resource management tools employees increase their skills, motivation and involvement (Walton, 1985; Appelbaum and Berg 2001). Workers receive greater participation in decision-making, opportunities to learn new skills, greater autonomy and, sometimes, financial incentives to increase effort and productivity. This results in workers having a greater sense of personal control and efficacy 
(Voydanoff 1988) and greater intrinsic job satisfaction (Appelbaum et al 2000). The specific practices typically include some combination of team working, quality circles, the ability to express opinions about, and influence, managerial decisions, employee training and performance pay.

Critics of HPWs argue that while the real consequences might include a higher level of performance for the enterprise, workers have greater effort, stress, hours and lower job satisfaction. Thus Ramsay et al. (2000) uses the UK 1998 Workplace Employee Relations Survey to show that workers in HPWs report greater job strain and lower pay satisfaction. Gallie et al. (1998) use earlier survey data to show the characteristics of HPWs are associated with greater "work pressure" for employees. Godard (2001) uses a North American survey showing that employees of HPWs report lower overall job satisfaction and lower self-esteem both of which flow from work considered more stressful. While we do not take a position on the workplace consequences of HPWs, we note that both sides have strong views about the spillover from HPWs to life at home. Jones and Butler (1980) show that job challenge and variety (part of the intrinsic satisfaction proponents see associated with HPWs) relate positively with compatibility between family and work roles while Barnett et al (1992) show more generally that positive experiences at work can help alleviate stress at home. Berg et al. (2003) argue that participating in HPWs teaches skills that increase the 
ability to manage at home and that the personal control and efficacy associated with HPWs spill over into greater work-family balance. They test this hypothesis on a sample of US workers asked to what extent their employer helps them achieve "a balance between their work and family responsibilities." After holding constant a variety of family structure variables and job demands, they find that both specific indicators such as training and the opportunity to participate as well as a general measure of a high commitment environment positively influence workers' perceptions of the extent to which their employer helps in achieving work and family balance. $^{3} \quad$ This follows an earlier survey of firms by Osterman (1995) supporting his view that HPWs use family friendly practices as part of their human resource strategy designed to create high levels of commitment from employees. Workers with high levels of commitment will be more likely to put forth discretionary effort on behalf of their employer and workers who feel that their job disrupts the rest of their life will not have this commitment. In Osterman's representative sample of medium and large firms, those with high performance workplaces are significantly more likely to offer programs designed to integrate work and family. Batt and Valcour (2003) present evidence that the provision of family friendly practices alone is not sufficient to alleviate work-family conflict. Instead, it is necessary that such policies be integrated into a redesigned, high performance, workplace. In this way, HPWs represent the proper bundling of human resource practices including family friendly practices. 
Those who see HPWs as creating more time consuming and stressful jobs anticipate negative spillovers to family life (Maume and Houston 2001). Participating in teams or groups generates peer pressure. Taking responsibility for participation and self-direction, especially when coupled with performance appraisal, causes stress. In a zero-sum game in which workers allocate commitment between work and home, a high commitment workplace means less commitment to home. As White et al. (2003 p. 179) state, "practices that increase work demands increase negative work-to-home spillover." To measure the extent of negative spillover, White et al. (2003) develop an index based on worker perceptions about home and work balance with higher numbers indicating greater negative spillover. The three parts of the index come from the Working in Britain 2000 and Employment in Britain 1992 surveys. They identify whether or not the workers have the time they would like to carry out family responsibilities, whether or not workers feel their job prevents them from giving the time they would like to their family, and whether or not the worker's family is "fed up" with the pressure of the worker's job.

Controlling for family structure, they find that the index tends to be significantly higher when hours are greater and when appraisal systems are used. Other results are less convincing but group working arrangements also appear associated with higher negative spillover. The evidence on performance related pay paints the least clear picture: when workers feel pay incentives influence their effort, the index increases - but individual performance-related pay and profit 
sharing is associated with reduced negative spillover. White et al. concluded that their results show that employees do not always benefit from high performance work practices and that employers need "a more fundamental approach" that seeks to build into work practices safe guards for work family balance.

Note that Wood (1999) reworked Osterman's data finding that an integrated package of family friendly practices is simply unrelated to HPWs in the US and apparently has found a similar result for the UK (see White et al. 2003 p. 179). Also, note that the view of a negative spillover is not the only one that predicts a negative association between HPWs and work family balance. Hochschild (1997) claims that HPWs with their participatory and supportive environments actually become havens from stresses and conflicts of home. HPWs have many good effects on workers but they do not spillover to home but rather cause workers to substitute away from home. In her view, HPWs cause workers to spend more time at work where their commitment is valued in order to avoid home. ${ }^{4}$

\section{A New Framework for Testing}

In setting-up our empirical contribution, we begin with several underpinnings. As our first underpinning, we emphasize the importance of asking workers about their employers family friendly work practices. This is critical because management simply saying such practices exist 
need not indicate a meaningful set of practices. First, management may establish family friendly practices but create a work environment that discourages their use. Budd and Mumford (2005) found a huge difference between the availability of five family friendly work practices and their perceive accessibility by the workers within UK firms. They conclude establishment level indicators of the availability of such practices "drastically overstate" workers perceived availability and go so far as to suggest that British workplaces appear to be responding "disingenuously" to pressure to enhance family friendly work practices. Second, even assuming workplaces respond genuinely, co-workers can influence a workers perception of accessibility. Kirby and Krone (2002) emphasize that the nature of co-workers communication is critical as when they complain about "picking up the slack" for those on leave or taking advantage of flexible hours policies. Third, the demands of the worker's job may mean that even though the practices are available, and co-workers are supportive, they are not used. Blair-Loy and Wharton (2004) show that workers with the heaviest job demands are most likely to feel unable to use existing family friendly policies. This may be particularly important given the view by some that HPWs dramatically increase job demands. Thus, even if Osterman is correct and HPWs are more likely to have family friendly practices, this does not guarantee that workers will feel free to use them. Finally, an establishment may have no explicit family friendly policies but have a general attitude of accommodation or have individual supervisors who accommodate 
workers' family responsibilities. As a consequence, the family friendly nature of the workplace may be best assessed by worker's perceptions of their employer's ability to allow them to fulfill family responsibilities not by an itemized list of specific practices.

As our second underpinning, we emphasize the importance of time to devote to family as a critical, and perhaps the most critical, dimension of family friendly policies. Parental leaves, flexibility over hours, job-sharing, career break schemes and many other formal practices are each about providing time when workers need it to attend to matters at home. White et al. (2003 p. 180) argue that the consequences of negative spillover will be reduced by any workplace practice that increases employee choice or flexibility over their job demands and that these typically involve providing choice and flexibility over the time devoted to work. Thus, in measuring the extent of family friendly practices we adopt a time-based measure. Specifically, the measure indicates the extent to which workers feel the employer provides sufficient time to attend to family responsibilities. This measure has the advantage of allowing both formal and informal practices to enter into the worker's calculus. Thus, an accommodating supervisor could result in a family friendly workplace even without any formal practices. Moreover, this measure implicitly allows the worker to decide the amount of time needed to attend to family responsibilities.

In our third underpinning, we take seriously the concern by Budd and Mumford (2005) 
that explicit policies may falsely advertise a family friendly environment. Firms may have policies that they hope employees will not use. Indeed, firms or coworkers may even discourage workers from using these policies. We think this point takes on special relevance in discussing HPWs, as one of the critical components of such workplaces is increased commitment by workers. Yet, as organizational behaviour theorists make clear, commitment should run both ways, giving rise to a "psychological contract" between the organization and the worker (Guest, 1998; Coyle-Shapiro and Kessler, 2000). The organization that cares for employee contributions and for employee well-being creates an incentive for employees to reciprocate - to demonstrate organizational citizenship behaviour (Coyle-Shapiro and Kessler, 2000). ${ }^{5}$ A breach of the psychological contract lowers trust, reduces organizational citizenship behaviour, and in turn lowers performance. HPWs redesign workplaces, making investments in worker skills, and providing for and acting upon the input of involved workers. These are precisely the type of match specific investments associated with increased intensity of commitment. Such investments make the loss of existing workers more costly and increase the incentive to keep promises made to them (Jovanovic 1979, Drewianka 2005). Thus, at a fundamental level the success of HPWs depends on keeping the promises made (either explicitly or implicitly) to their employees. Regardless of whether the new bargain made at work benefits workers on balance or not, the HPW can survive only when employers live up to their side of the bargain. Indeed, 
Burud and Tumolo (2004) go so far as to contend that family friendly policies are only likely to be successful as part of a broader workplace strategy designed to increase commitment of both sides to the success of the employment relationship.

Thus, our measure of whether employers provide the time needed to attend to family responsibilities consists of two parts. The first asks if the worker feels the employer made a commitment (either an explicit or implicit promise) to provide this time. The second measures whether or not (and ultimately how well) the worker feels the employer fulfilled that commitment. This distinction allows us to draw on past literature to identify two testing questions. First, are HPWs more likely to make commitments to provide needed family time? As made clear, past evidence and theory stands as too mixed to hazard a prediction. Second, are HPWs more likely to keep the commitments that they make to provide needed family time?

Here, we follow the argument above and the basic meaning of commitment in the HPW to predict that HPWs are more likely to keep the commitments they make. If this prediction is correct, HPWs will emerge as more family friendly environment unless they are significantly less likely to make commitments in the first place. We now turn to describing our data and testing framework.

\section{Data and Methodology}

We draw our data from Working in Britain 2000. This survey was commissioned by the UK 
Policy Studies Institute and conducted by Public Attitude Surveys, as part of the research study Changing employment relationships, employment contracts and the future of work funded by the Economic and Social Research Council (ESRC). The survey used a probability sampling method to develop a national sample of 2,466 employed people aged 20-60, with a response rate of $65 \%$. White et al. (2000) provide the details of this survey. ${ }^{6}$

We adopt this survey because of the unique questions that form the dependent variables in our estimations. Workers were asked if their "employer made an explicit or implicit commitment to allow employees time off to fulfill family responsibilities." An immediate follow-up question asks workers "how well their employer has kept that commitment" if made. The answers to the follow-up take a five point Likert scale from "not at all" to "very well". We examine both the determinants of the Likert scale variable and a dichotomous variable simply indicating whether or not the commitment is kept. Three possibilities emerge from the structure of the two dichotomous variables: 1 . the employer makes no commitment; 2. the employer makes a commitment and keeps it; 3. the employer makes a commitment and does not keep it. As the top panel of Table 1 shows, the share of workers who feel their employer has made an explicit or implicit commitment to provide the needed time for family responsibilities is a surprisingly high 84 percent. Admittedly this figure is far above typical estimates of the share of employees who have family friendly jobs as measured by specific practices. Thus, Heywood 
et al. (2005) have suggested that around a third of UK workers had jobs with formal family friendly practices in 1998. Yet, it is important to understand that the 84 percent figure reflects the workers' perception of both the informal as well as the formal practices that allow needed time and includes the workers implicit decision over the amount of time needed to fulfill family responsibilities. Clearly formal practices should not be taken as a necessary condition for workers to view their jobs as providing the needed time for family.

The indicator of whether or not employers keep their commitment takes a mean of .89. Thus, nearly nine of ten workers who felt their employer made a commitment also felt they kept this commitment with the consequence that 75 percent (.89 times .84) of workers felt their employer both made a commitment and kept that commitment. That nearly three-fourths of workers feel their employer provides them time to fulfill family responsibilities fits with the review by MacInnes (2005 p. 277) of the UK official statistics, and also the US time-diary evidence (Robinson and Godbey 1999) that "work has hardly been devouring time for the family." Nonetheless, as only a small minority of workers have young children at home, it might be considered alarming that a quarter of all workers report that they do not receive the needed time from their employer. Either their firm made no commitment to provide it (16 percent of the sample) or their firm made a commitment that they do not keep ( 9 percent of the sample). Certainly, this last (9 percent) category supports the concern of Budd and Mumford (2005) 
that some firms may provide family friendly practices under pressure but then not make them meaningful or useful to their workers. This category also interests us as it contains the broken promises - breaches of the psychological contract - behavior antithetical to successful HPWs. Certainly, workers with employers in this category report substantial consequences. Table 2 provides answers to the worker question of whether or not their job prevents them from giving the time they would like to their family. The result is dramatic, showing that those workers who felt their employer broke a commitment are much more likely to feel their job prevents them from giving the time they desire to the family. In fact, those who feel prevented from giving the time they desire to their family are seven in ten for workers whose employer broke a commitment, while only four in ten both for workers whose employer kept a commitment and workers whose firm never made a commitment. These results may suggest that workers sort among employers based on the perception of a commitment but only upon employment find out whether or not the employer keeps the commitment. Thus, workers in the broken commitment category may be those not well matched or sorted incorrectly.

Having established the importance of breaking a perceived commitment we now examine empirically the determinants of three commitment states based on the first two variables identified in Table 1. Thus, we are interested in whether or not HPWs are more likely to make a commitment in the first place and whether or not they are more likely to keep a commitment if 
they made it. Finally, to confirm the findings of these two estimates, we test whether or not HPWs are more likely to be among the employers who both make and keep a commitment. Identifying the nature of these links requires identifying the characteristics of HPWs available in the data. Here, we follow the literature (e.g., Guest et al, 20003; Capelli and Neumark, 2001) in making this identification, as shown in Panel 2 of Table 1. We include measures of autonomy and influence (design aspects of own work, decide specific tasks, say over decisions), participation and involvement (formal suggestion schemes, informational meetings, whether or not the worker can express views to management on firm activities, say over decisions), group working (regular group meetings to discuss improvements) and training (training provided by employer to the worker in the last two years). These eight variables capture critical aspects of HPWs with their increased opportunities for involvement, participation, initiative, group working and training. Excluded from this list are indicators of performance appraisal or performance pay. We recognize these as potentially important characteristics but note that each may also be included in more traditional work environments. Thus, individual performance pay (say a piece rate) would tend to indicate the absence of a HPW and we note that individual performance pay typically requires formal performance appraisal (Brown and Heywood 2005). The combination associated with HPWs would more likely be group or higher pay schemes coupled with appraisal. While we do not include such variables as indicators of 
HPWs, we do include these variables in the estimations in order to track their consequences.

Thus, all estimations include an indicator for formal appraisal and indicators for both group/organizational performance pay and for profit sharing. As will be clear, these variables do not materially change the quantitative results. Certainly, this approach fits the rather indeterminate link between performance pay, as an element of HPWs, and family friendly practices as shown by White et al. (2003).

While we separately examine the influences of all eight indicators, we also aggregate them to a single indicator of HPWs. The aggregation follows a k-mean cluster as shown in Table 3. The clustering gives a very clear pattern with HPWs having substantially more of each of the underlying characteristics. Thus 72 percent of workers in HPWs received training compared with only 27 percent in other workplaces. Similarly, 93 percent of those in HPWs can express their views to management in a meeting compared with less than 40 percent in other workplaces. The differences in the means between the sample workers in HPWs and not in HPWs are statistically significant for every single underlying indicator. The clustering suggests that 42.7 percent of workers have jobs and employers with the characteristics of HPWs.

The testing methodology begins by estimating three probit equations on the commitment variables discussed above focusing on the characteristics associated with HPWs and controlling for other broad groups of control variables. The third panel of Table 1 outlines the first group 
of controls. These measure the worker's family structure as a way of controlling for the demands for time at home to fulfill responsibilities. They include five indicators that identify whether or not there are full-time caregivers at home using underlying variables on marital status, number of workers and the presence of dependent children. The excluded category is not married without dependent children. We also control for whether or not the worker is responsible for regular care of a disabled or elderly relative.

While recognizing the point by MacInnes (2005) that these structure variables need not be critical (as hours of work can be adjusted), our perspective is that family structure variables should have different influences on our underlying dependent variables. The expectation is that workers not married with children, or with a working spouse and children, or caring for relatives will be more likely to work for an employer who provides a commitment as it is more valuable for such workers. Thus, in searching for work they seek out such employers and are more willing to pay any earnings reductions associated with family friendly policies. On the other hand, not having a full time caregiver may make the commitment of an employer appear inadequate with the result that these same workers are more likely to feel their employer has not kept the commitment. The net effect on whether such workers are more likely to have an employer who both makes and keeps a commitment is thus ambiguous.

The fourth panel of Table 1 identifies a series of further individual controls including the 
worker's gender, age, tenure on the job, and educational and professional qualifications. Then the fifth panel of Table 1 identifies a series of workplace controls including, as discussed, two measures of performance pay and the presence of formal performance appraisal. Also included are indicators for part time and permanent job status, union status, government employment, firm size, the availability of a pension and sick pay. For some specifications we also include hours worked per week, whether or not working long hours is a requirement of the job, whether or not output target is set, an indicator of job stress and three indicators of job satisfaction. Finally, we also control for broad occupation (seven categories) and for broad industry (twelve categories). While this long list may cause the fear that we have over controlled (that the true influence of HPWs flows through some of the controls), we undertake extensive specification alterations to be convinced this is not the case.

\section{Results}

The first column of Table 4 presents the probit estimation of the determinants of whether or not workers feel their firm has made a commitment to provide the time needed to fulfill family responsibilities (Comit). As with all the specifications, the estimate employs the sample weights to adjust for the sampling structure. The first set of variables show the role of family structure. While five of six coefficients are positive, only one takes a statistically significant 
coefficient. Those workers who have children and a working spouse report they are more likely to work for an employer who has made a commitment. The second set of variables shows the results for the characteristics of HPWs. Only one of the eight coefficients is statistically significant. Those workers who have group meetings at which they can express their views are significantly more likely to have employers who have made a commitment. This specification controls for only a parsimonious set of other characteristics and shows that permanent workers are more likely to report their employer has made a commitment. The second column reproduces the estimation with the complete set of other controls. Primary among the changes is that now two HPW characteristics emerge. However, the coefficients are of virtually identical size and significance but of opposite signs. Moreover, the significant indicator from the more parsimonious specification no longer remains so. Thus, on balance there appears to be little or no consistent relationship between the characteristics of HPWs and making a commitment to providing time for family. It is worth emphasizing that in the more complete specification neither performance appraisal nor group/organizational performance pay nor profit sharing plays a significant role.

The third and fourth columns replicate the specification changing the dependent variable to whether or not the employer has kept its commitment and limiting the sample to those workers who report their employer made a commitment in the first place (Kcomit if Comit=1). The first 
panel shows the more parsimonious specification and indicates that family structure is very important. All three dummies indicating the presence of children and the dummy indicating care of a relative are associated with reduced probabilities of the employer keeping the commitment. The sum of the two estimations regarding the family structure variables fits the expectation that those with greater demands at home are both more likely to select into a firm that has made a commitment, and yet are more likely to feel the employer has not fulfilled that commitment.

The high performance indicators remain somewhat mixed but the tendency is clearer. Three of the four significant indicators emerge with positive coefficients. Having a say, having group meetings in which voice opinions and setting own tasks are all positive determinants of an organization keeping its commitment. Moreover, the sum of the four significant coefficients remains a very large, .896, implying that if a worker's job has all four significant HPW characteristics, the chance that the employer kept the commitment is high.

The other controls indicate that part time workers and those with pensions are more likely to have employers who kept their commitment.

The specification with the complete set of controls causes only modest alterations. Now three rather than four family structure variables are negative determinants of keeping the commitment. Among the HPW indicators, now five are statistically significant with four large 
positive determinants of keeping the commitment. The additional controls indicate that longer hours and feelings of job stress are both negative determinants of keeping the commitment. Importantly, the positive role of HPWs in keeping the commitment emerges either with or without these controls. Thus, any relationship that hours and stress may have with the HPW indicators does not drive the result that HPWs are more likely to keep their commitment to provide time for family responsibilities. Satisfaction with promotion possibilities appears as a positive determinant of keeping the commitment. Using appraisals and profit sharing are not associated with keeping the commitment among those firms that have made a commitment. Yet, group/organizational performance pay does emerge as a negative determinant of employers keeping the commitment, a point to which we will return to shortly.

The fifth and sixth columns present the determinants of workers reporting that their employers both made and kept the commitment to provide the needed time (Kcomit). Thus, the other possibility includes both employers that did not make a commitment and those that made a commitment but did not keep it. The estimated coefficients reflect both the determinants of making a commitment in the first place (from columns 1 and 2) and of keeping that commitment (columns 3 and 4). As anticipated, these two influences cancel out each other when it comes to family structure. None of the coefficients is statistically significant and an equal number take positive and negative signs. This result fits with the evidence that MacInnes (2005) presents that 
workers with young children and greater demands at home are no more likely to wish reduced hours.

The characteristics of high performance workplaces predominately reflect their positive influence on keeping the commitment once made. Thus, three of four significant coefficients take positive signs. The total influence of all four significant variables is also strongly positive. Moreover, if one moves to the expanded specification in column six, the one negative significant coefficient vanishes leaving three positive and significant coefficients. Thus, those characteristics associated with HPWs are also associated with greater provision of the needed time to fulfill family responsibilities. This happens not because these characteristics are associated with a greater likelihood to make a commitment to its workers to provide this time, but rather from a greater likelihood of keeping such a commitment once it is made.

The other controls indicate that workers with part time jobs, permanent jobs and pensions are more likely to work for a firm that provides the needed time. The only variable from the expanded specification that now plays a role is the indicator of job stress. Those workers who report greater job stress are less likely to work for firms that provide the needed time to attend to family. Importantly, neither the number of hours of work nor the use of group/organization performance pay emerges as important. While both were associated with a reduced probability of keeping the commitment, they were not sufficiently large influences to overcome insignificant 
but positive coefficients in the estimate of the probability of making that commitment in the first place. Thus, even if one felt appraisal, profit sharing and group pay schemes belonged as indicators of HPWs, it is clear that they have no influence on the provision of the needed time to meet family responsibilities while many of the other characteristics have a positive influence on the provision.

The estimates in Table 5 repeat those of Table 4 but substitute the composite index of HPWs for the individual characteristics. The pattern of the family structure variables remains as before, positively influencing the making of a commitment as workers sort, but negatively influencing the keeping of the commitment with no net effect on overall provision of the needed time. The pattern of controls remains identical. Most importantly, the composite high performance index reveals precisely the same pattern as the individual characteristics. When the worker's employer provides a high performance workplace, the making of a commitment is neither more nor less likely. Yet, having made such a commitment, HPWs are more likely to fulfill the commitment. This result fits with our prediction that successful HPWs aim to maintain trust, and so develop a structure of mutual obligation. This influence is sufficiently strong that on balance HPWs are more likely to simultaneously make and fulfill a commitment to provide the time needed to meet family responsibilities than are other workplaces. ${ }^{7}$

Table 6 uses the full detail of the variable on keeping the commitment. This variable 
ranges over a five point Likert scale with higher values indicating a more fully kept commitment. The resulting estimation must account for this ordering. The resulting ordered probits provide more depth to the simple probit estimations of columns 3 and 4 of Tables 4 and 5 . They indicate a somewhat less robust pattern for family structure. In the parsimonious specifications, those with a spouse but no child are more likely than those without a spouse and without a child to feel their employer has kept their commitment (again limited to the sample that made a commitment). In the expanded specification, those not married with a child are significantly less likely to have an employer that kept its commitment.

The pattern of controls reveals more significant determinants than was the case for the dichotomous dependent variable. Those with permanent jobs, part time jobs and pensions are more likely to report their employer did a better job in keeping the commitment. Also echoing the earlier results, those with greater job stress and with sick pay report lower success in keeping the commitment. New results include a modest indication that those working in smaller firms do a worse job keeping the commitment (the largest firms are the excluded category). In addition, there are signs that those required to work long hours have firms doing a worse job (although the relationship is only weakly significant and only when the high performance index is used). The satisfaction variables emerge as highly important. Higher levels of satisfaction with promotion possibilities and with coworkers are both associated with increased success in 
keeping the commitment. Similarly, the higher the intrinsic reward index, the greater the success in keeping the commitment. Importantly, in these specifications there is no indication that appraisal, profit sharing or group/organizational performance pay influences the success in keeping the commitment.

An interesting result emerges regarding union members. Members report their employers do less well than nonmember's firms in keeping the commitment. This may reflect that the set of family friendly practices designed in unionized workplaces are less useful in keeping the commitment. Budd and Mumford (2004) make clear that UK unions are associated with reduced availability of flexible hours and work at home arrangements but greater availability of leaves and job sharing. It also remains possible that the negative coefficient reflects union voice. Unions may encourage a culture of complaint in order to effect change and this culture is reflected in lower reported job satisfaction (see Heywood et al. 2002) including satisfaction with employers keeping a commitment to provide family time.

Finally, the results with the more detailed measure of keeping the commitment replicate the results for the role of HPWs. The same three characteristics are positive and significant determinants of success in keeping the commitment in both the short and long specification: a lot of say in own work, ability to express opinions to management in meetings, and setting one's own tasks. The high performance index stands out as among the very most important 
determinants of success in fulfilling the commitment. Both the coefficients and t-statistics are either the largest or second largest among all variables in the two specifications.

\section{Conclusions}

We have predicated this inquiry on the assumption that workers' assessment of available time to attend to family responsibilities best identifies work family balance. We explore whether or not firms provide this time but we do so by examining two stages in this provision: first, has the firm committed (implicitly or explicitly) to provide this time and second, has the firm kept its commitment if made.

Using this framework, we explore the controversy over the relationship between high performance workplace and the provision of family friendly practices. We hypothesize that while past theory and evidence remains too contradictory to predict a relationship in the first stage of this provision, that HPWs should be more likely to keep a commitment if made. Such workplaces depend on high levels of commitment from workers, commitment that reflects investments workers are being asked to make in the specific employment relationship, and which will be made only if employers also make such investments. We argue that keeping promises on family friendly practices thus represents one way in which the HPW builds up shared perceptions of mutual obligation, and so maintains a high investment and high effort workplace. 
We have found that HPWs are no more likely to make commitments in the first place, but are indeed more likely to keep them once made. The implication is that HPWs do motivate by building up perceptions of mutual obligation, and in the present context, that they care for employee work-life balance. As a consequence, the evidence confirms that HPWs are more likely to both make and keep a commitment to provide family friendly practices. 
Table 1. Variable meanings and descriptive statistics

Variables Meanings (means, standard deviations)

Dependent variables:

Comit_ff Dummy=1 if an employer has made explicit/implicit commitment to allow employees time off for family responsibilities $(.844, .363)$

Kcomit_ff Dummy=1 if employees think that the employer has made and kept his/her commitment extremely, very or fairly well $(.750, .433)$

Okcomit_ff Ordered index for employees’ assessment on how well their employers kept their commitment (4=extremely well, 3=very well, 2=fairly well, $1=$ not very well, and $0=$ not at all well) $(2.658,1.030)$

\section{Independent variables:}

1. High performance management measures

HPM_index Index variable derived from the k-mean clustering analysis (1 for high performance management firm; 0 for otherwise) $(.427, .495)$

Ownwork Dummy=1 if the employee can design and plan important aspects of his/her own work (.337, .473)

Owntask Dummy=1 if the employee can decide the specific tasks that he/she carries out from day to day $(.498, .500)$

Iinvdewk Dummy=1 if an employee reports that he/she has a great deal or quite a lot of say to decisions that change the way he/she does work. $(.324, .468)$

Sugg_sch Dummy=1 if the organization has a formal suggestion scheme $(.314, .464)$

Inf_meet Dummy $=1$ if the management organizes meetings to inform about what's happening in the organization $(.689, .423)$

Exp_meet Dummy=1 if the employee can express views about what is happening in the organization in meetings with management $(.628, .483)$

Groupm Dummy=1 if the organization has groups of employees who meet regularly to think of improvements $(.230, .421)$

Train Dummy=1 if the employee has received training either provided for or paid for by the employer during the past two years $(.463, .499)$

2. Family status variables

Ms_child Dummy=1 if married, single earner, with dependent children (age below 16) (.060, .238)

Ms_nchild Dummy=1 if married, single earner, with no dependent children (.055, .229)

Md_child Dummy=1 if married, dual earner, with dependent children $(.278, .448)$

Md_nchild $\quad$ Dummy=1 if married, dual earner, with no dependent children (.278, .448)

Nm_child $\quad$ Dummy $=1$ if not married but with dependent children $(.063, .243)$ 
Regcare Dummy=1 if regularly spending time caring for a disabled or elderly relative (.097, .296)

3. Other individual characteristics

Male Dummy=1 for male (.474, .499)

Age $\quad$ Age of respondent $(38.513,10.999)$

Tenure $\quad$ Months of tenure with current employer (77.896, 87.852)

Hdegree $\quad$ Dummy $=1$ for degree or higher degree holders (.157, .364)

Sdegree Dummy=1 for sub-degree holders (.093, .291)

Alevel Dummy $=1$ for A-level or equivalent qualifications (grade 13) $(.107, .309)$

Olevel Dummy $=1$ for O-level or equivalent qualifications (grade 11) $(.251, .434$ )

Cse Dummy $=1$ for CSE or equivalent qualifications (grade 9) $(.126, .332)$

V_quali Dummy=1 for holding any vocational qualifications (.463, .499)

P_quali Dummy $=1$ for holding any professional qualifications (.172, .377)

4. Other job characteristics

Ppay Dummy 1 for group or organization based performance related pay $(.239, .427)$

Pshare Dummy=1 for profit sharing or share-option schemes $(.119, .324)$

Apprais Dummy $=1$ if the firm has a formal appraisal system (.520, .500)

Ptime Dummy=1 if holding a part time job (.289, .454)

Pjob Dummy $=1$ if holding a permanent job $(.895, .306)$

Union Dummy $=1$ for union members $(.316, .495)$

Public Dummy=1 if in public sector (.302, .459)

Fsize1 Dummy=1 for organization size under $50(.515, .500)$

Fsize2 Dummy=1 for organization size between 50 to $100(.111, .314)$

Fsize3 Dummy=1 for organization size between 100 to $500(.188, .391)$

(The omitted size category is 500 or above)

Pension Dummy=1 if the employer provides an occupational pension scheme beyond the basic state scheme $(.585, .493)$

Sickpay Dummy $=1$ if the employer provides sick pay scheme beyond the basic government scheme (.586, .492)

Whours Hours of work per week $(37.089,15.536)$

Longhr Dummy=1 if it is important to work long hours because it is a requirement of the job or refusing to do so could cost an employee his/her job (.392, .488)

Target Dummy=1 if an explicit output target is set for the employee $(.591, .492)$

Jstress Index of feeling under excessive pressure at work (4=all the time, $3=$ =quite often, $2=$ every now and then, $1=$ rarely, and $0=$ never $)(2.168, .948)$ 


\begin{tabular}{ll}
\hline Satcowk & $\begin{array}{l}\text { Satisfaction with co-worker index (6=completely satisfied, 5=very satisfied, } 4=\text { satisfied, } \\
\text { 3=neither satisfied nor dissatisfied, } 2=\text { dissatisfied, } 1=\text { very dissatisfied, and } 0=\text { completely } \\
\text { dissatisfied) }(4.732, .924)\end{array}$ \\
Satprom & $\begin{array}{l}\text { Satisfaction with promotion opportunity index (same as above) }(3.315,1.281) \\
\text { Inreward }\end{array}$ \\
& $\begin{array}{l}\text { Index of intrinsic rewards of the job (sum of the job satisfaction index over the following } \\
\text { aspects: (1) the challenge the job sets you; (2) the scope for personal responsibility; (3) } \\
\text { the chance to help other people; (4) the chance to develop yourself; (5) the opportunity to } \\
\text { do something worthwhile; (6) the chance for personal achievement. Each index value } \\
\text { same as for Satcowk) }(24.393,5.834)\end{array}$ \\
\hline Sample size & 1309
\end{tabular}

Note: The regression analyses also include 6 occupational dummies and 11 industry dummies. 
Table 2. Employees' Perception of Employers' Commitment to Family Friendly and Whether or Not Jobs Prevent Time for Family

\begin{tabular}{|l|c|c|c|}
\hline & \multicolumn{2}{|c|}{$\begin{array}{l}\text { Employer made/kept their commitment to provide time off for } \\
\text { family requirements }\end{array}$} & $\begin{array}{c}\text { Made but not kept } \\
\text { well }\end{array}$ \\
\hline $\begin{array}{l}\text { Job prevents giving } \\
\text { the time I like to my } \\
\text { partner or family }\end{array}$ & $\begin{array}{c}\text { Not made } \\
\text { Commitment }\end{array}$ & $425(42 \%)$ & $86(69 \%)$ \\
\hline $\begin{array}{l}\text { Yes (almost always } \\
\text { or often) }\end{array}$ & $72(35 \%)$ & $578(58 \%)$ & $39(31 \%)$ \\
\hline $\begin{array}{l}\text { No (sometimes, } \\
\text { rarely, or never) }\end{array}$ & $135(65 \%)$ & 1003 & 125 \\
\hline Total & 207 & & \\
\hline
\end{tabular}

Note: The proportion who answer yes among those working for a firm that did not keep its promises is significantly greater than either of the other two proportions that answer yes (at the one percent level). At the same level, the hypothesis that those other two proportions are identical cannot be rejected.

Table 3: K-mean Clusters to Create the High Performance Workplace Index

\begin{tabular}{|l|c|c|c|c|c|c|c|c|}
\hline & Iinvdewk & Inf_meet & Exp_meet & Sugg_sch & Groupm & Ownwork & Owntask & Train \\
\hline $\begin{array}{l}\text { Hpindex } \\
(57.3 \%)\end{array}$ & .163 & .499 & .397 & .264 & .048 & .135 & .285 & .274 \\
\hline $\begin{array}{l}\text { Hpindex } \\
=1 \\
(42.7 \%\end{array}$ & .544 & .949 & .926 & .384 & .473 & .610 & .773 & .723 \\
\hline
\end{tabular}

Note: Mean values are reported in the cells and the differences between the means are all statistically significant at the 5 percent level. 
Table 4. Probit Regression Results (with individual HPM measures)

\begin{tabular}{|c|c|c|c|c|c|c|}
\hline \multirow{3}{*}{\begin{tabular}{|l|} 
Independent \\
Variables \\
\end{tabular}} & \multicolumn{6}{|c|}{$\begin{array}{c}\text { Dependent Variables } \\
\text { (mean) }\end{array}$} \\
\hline & \multicolumn{2}{|c|}{$\begin{array}{c}\text { Comit_ff } \\
(\mathbf{0 . 8 4})\end{array}$} & \multicolumn{2}{|c|}{$\begin{array}{c}\text { Kcomit_ff (if Comit=1) } \\
(\mathbf{0 . 8 9 )}\end{array}$} & \multicolumn{2}{|c|}{$\begin{array}{c}\text { Kcomit_ff } \\
(0.75) \\
\end{array}$} \\
\hline & Model I & Model II & Model III & Model IV & Model V & Model VI \\
\hline \multicolumn{7}{|c|}{ 1. Family status variables } \\
\hline Ms_child & $.145(.81)$ & $.250(1.12)$ & $-.361(1.72)^{*}$ & $-.377(1.53)$ & $-.053(.34)$ & $.023(.12)$ \\
\hline Ms_nchild & $-.0004(.00)$ & $-.050(.22)$ & $.439(1.50)$ & .531 (1.39) & $.168(.90)$ & $.111(.51)$ \\
\hline Md_child & $.319(2.26)^{* *}$ & $.328(2.05)^{* *}$ & $-.415(2.5)^{* *}$ & $-.524(2.86)^{* * *}$ & .035 (.29) & $.014(.10)$ \\
\hline Md_nchild & $.100(.74)$ & $.141(.93)$ & $-.026(.14)$ & $-.277(1.42)$ & $.051(.41)$ & $-.061(.43)$ \\
\hline Nm_child & $.114(.57)$ & $-.028(.13)$ & $-.353(1.63)^{*}$ & $-.441(1.85)^{*}$ & $-.101(.59)$ & $-.222(1.18)$ \\
\hline Regcare & $.051(.32)$ & $-.002(.01)$ & $-.309(1.67)^{*}$ & $-.422(2.12)^{* *}$ & $-.187(1.31)$ & $-.303(1.89)^{*}$ \\
\hline \multicolumn{7}{|c|}{ 2. High performance management measures } \\
\hline Ownwork & $-.115(1.01)$ & $-.257(2.01)^{* *}$ & $.176(1.18)$ & $.152(.88)$ & $-.009(.09)$ & $-.127(1.05)$ \\
\hline Owntask & $.131(1.23)$ & $.249(2.06)^{* *}$ & $.357(2.65)^{* *}$ & $.290(1.93)^{*}$ & $.228(2.36)^{* *}$ & $.276(2.52)^{* *}$ \\
\hline Iinvdewk & $.055(.52)$ & .088 (.68) & $.327(2.43)^{* *}$ & $.525(3.14)^{* * *}$ & $.179(1.86)^{*}$ & $.276(2.38)^{* *}$ \\
\hline Sugg_sch & $-.149(1.26)$ & $-.134(1.02)$ & .-.163 (1.18) & $-.207(1.38)$ & $-.180(1.73)^{*}$ & $-.163(1.41)$ \\
\hline Inf_meet & $.096(.72)$ & $.063(.41)$ & .039 (.23) & $.112(.59)$ & $.077(.62)$ & $.060(.43)$ \\
\hline Exp_meet & $-.070(.55)$ & $-.140(.96)$ & $.528(3.14)^{* *}$ & $.406(2.34)^{* *}$ & $.207(1.73)^{*}$ & $.120(.92)$ \\
\hline Groupm & $.253(1.91)^{*}$ & $.179(1.24)$ & $-.316(2.05)^{* *}$ & $-.353(2.02)^{* *}$ & $.016(.13)$ & $-.040(.31)$ \\
\hline Train & $.058(.53)$ & $.084(.67)$ & $.124(.99)$ & $.304(2.22)^{* *}$ & .117 (1.23) & $.172(1.68)^{* *}$ \\
\hline \multicolumn{7}{|c|}{ 3. Other job characteristics } \\
\hline Pjob & $.290(1.92)^{*}$ & $.303(1.67)^{*}$ & $.144(.77)$ & $.263(1.26)$ & $.277(1.99)^{* *}$ & $.318(1.95)^{* *}$ \\
\hline Ptime & $-.167(1.34)$ & $-.190(1.10)$ & $.793(4.66)^{* * *}$ & $.365(1.80)^{*}$ & $.187(1.66)^{*}$ & $.036(.23)$ \\
\hline Union & $.123(.97)$ & $.004(.03)$ & $-.158(1.03)$ & $-.224(1.36)$ & $.035(.31)$ & $-.067(.53)$ \\
\hline Public & $.017(.12)$ & $-.068(.39)$ & $.184(.99)$ & $.164(.79)$ & $.049(.37)$ & $-.035(.24)$ \\
\hline Fsize1 & $-.226(1.46)$ & $-.287(1.59)$ & $.096(.56)$ & $-.144(.75)$ & $-.125(.92)$ & $-.243(1.60)$ \\
\hline Fsize2 & $-.030(.16)$ & $-.096(.45)$ & $-.004(.02)$ & $-.195(.85)$ & $-.014(.08)$ & $-.149(.80)$ \\
\hline Fsize3 & $.222(1.26)$ & $.178(.89)$ & $-.074(.40)$ & $-.240(1.18)$ & $.087(.60)$ & $-.008(.05)$ \\
\hline Pension & $.093(.70)$ & $.143(.93)$ & $.552(3.16)^{* * *}$ & $.615(3.20)^{* * *}$ & $.296(2.43)^{* *}$ & $.373(2.70)^{* * *}$ \\
\hline Sickpay & $.184(1.58)$ & .107 (.79) & $-.096(.70)$ & $-.273(1.77)^{*}$ & $.077(.75)$ & $-.044(.37)$ \\
\hline Ppay & & $.090(.59)$ & & $-.445(2.96)^{* * *}$ & & $-.200(1.59)$ \\
\hline Pshare & & $-.051(.26)$ & & $.252(1.15)$ & & $.143(.85)$ \\
\hline
\end{tabular}




\begin{tabular}{l|l|l|l|l|l|l}
\hline Apprais & & $.167(1.34)$ & & $.002(.02)$ & & $.143(1.31)$ \\
\hline Target & & $.173(1.47)$ & & $-.195(.85)$ & & $.002(.02)$ \\
\hline Jstress & & $-.043(.71)$ & & $-.261(3.29)^{* * *}$ & & $-.156(2.87)^{* * *}$ \\
\hline Whours & & $.002(.43)$ & & $-.014(2.58)^{* * *}$ & & $-.004(.81)$ \\
\hline Longhr & & $-.023(.20)$ & & $-.053(.41)$ & & $.010(.10)$ \\
\hline Satcowk & & $-.004(.07)$ & & $.053(.72)$ & & $.037(.66)$ \\
\hline Inreward & & $-.020(1.85)^{*}$ & & $.019(1.45)$ & & $-.0002(.02)$ \\
\hline Constant & $.392(1.08)$ & $.890(1.60)^{*}$ & $.423(.97)$ & $.488(.73)$ & $-.131(.40)$ & $-.061(.12)$ \\
\hline Sample size & 1299 & 1065 & 1099 & 927 & 1309 & 1074 \\
\hline Pseudo R ${ }^{2}$ & .106 & .118 & .162 & .242 & .087 & .107 \\
\hline
\end{tabular}

Note: The regression analyses also included all other individual characteristics variables (gender, age, tenure, and 7 educational and professional qualifications dummies), 6 occupational dummies and 11 industry dummies. Sample weights are used. 
Table 5. Probit Regression Results (with HPM index measure)

\begin{tabular}{|c|c|c|c|c|c|c|}
\hline \multirow{3}{*}{$\begin{array}{l}\text { Independent } \\
\text { Variables }\end{array}$} & \multicolumn{6}{|c|}{ Dependent Variables } \\
\hline & \multicolumn{2}{|c|}{ Comit_ff } & \multicolumn{2}{|c|}{ Kcomit_ff (if Comit=1) } & \multicolumn{2}{|c|}{ Kcomit_ff } \\
\hline & Model I & Model II & Model I & Model II & Model III & Model IV \\
\hline \multicolumn{7}{|c|}{ 1. Family status variables } \\
\hline Ms_child & $.140(.78)$ & $.257(1.15)$ & $-.384(1.88)^{*}$ & $-.403(1.73)^{*}$ & $-.078(.50)$ & $.013(.07)$ \\
\hline Ms_nchild & $.010(.05)$ & $-.016(.07)$ & $.403(1.42)$ & $.467(1.28)$ & $.153(.84)$ & $.115(.54)$ \\
\hline Md_child & $.320(2.28)^{* *}$ & $.323(2.05)^{* *}$ & $-.374(2.28)^{* *}$ & $-.499(2.78)^{* * *}$ & $.033(.27)$ & $.002(.02)$ \\
\hline Md_nchild & $.108(.81)$ & $.151(1.00)$ & $-.031(.18)$ & $-.290(1.55)$ & $.046(.37)$ & $-.056(.40)$ \\
\hline Nm_child & $.123(.63)$ & $-.016(.07)$ & $-.333(1.56)$ & $-.466(2.02)^{* *}$ & $-.111(.65)$ & $-.233(1.25)$ \\
\hline Regcare & $.071(.45)$ & $-.025(.14)$ & $-.290(1.59)$ & $-.381(1.97)^{* *}$ & $-.162(1.12)$ & $-.270(1.67)^{*}$ \\
\hline \multicolumn{7}{|c|}{ 2. High performance management measure } \\
\hline Hpindex & $.078(.72)$ & $.048(.37)$ & $.431(3.41)^{* *}$ & $.410(2.73)^{* * *}$ & $.256(2.66)^{* *}$ & $.201(1.79)^{*}$ \\
\hline \multicolumn{7}{|c|}{ 3. Other job characteristics } \\
\hline Pjob & $.318(2.13)^{* *}$ & $.346(1.93)^{*}$ & $.172(.94)$ & $.252(1.19)$ & $.310(2.24)^{* *}$ & $.348(2.15)^{* *}$ \\
\hline Ptime & $-.187(1.50)$ & $-.215(1.24)$ & $.785(4.76)^{* * *}$ & $.441(2.20)^{* *}$ & $.188(1.66)^{*}$ & $.051(.34)$ \\
\hline Union & $.117(.90)$ & $.002(.02)$ & $-.211(1.45)$ & $-.284(1.78)^{*}$ & $-.007(.06)$ & $-.110(.88)$ \\
\hline Public & $.003(.02)$ & $-.090(.56)$ & $.207(1.16)$ & $.213(1.03)$ & $.058(.44)$ & $-.029(.20)$ \\
\hline Fsize1 & $-.204(1.39)$ & $-.270(1.56)$ & $.108(.65)$ & $-.145(.76)$ & $-.101(.78)$ & $-.227(1.54)$ \\
\hline Fsize2 & $-.030(.16)$ & $-.102(.48)$ & $-.011(.05)$ & $-.221(.95)$ & $-.003(.02)$ & $-.149(.81)$ \\
\hline Fsize3 & $.199(1.13)$ & $.130(.66)$ & $-.077(.43)$ & $-.266(1.31)$ & $.071(.49)$ & $-.048(.30)$ \\
\hline Pension & $.076(.59)$ & $.102(.66)$ & $.547(3.20)^{* * *}$ & $.620(3.26)^{* * *}$ & $.295(2.49)^{* *}$ & $.364(2.66)^{* * *}$ \\
\hline Sickpay & $.193(1.69)^{*}$ & $.147(1.11)$ & $-.084(.62)$ & $-.217(1.45)$ & $.097(.96)$ & $.002(.02)$ \\
\hline Ppay & & $.085(.56)$ & & $-.418(2.74)^{* * *}$ & & $-.184(1.46)$ \\
\hline Pshare & & $-.043(.22)$ & & $.218(1.02)$ & & $.121(.71)$ \\
\hline Apprais & & $.153(1.25)$ & & $.074(.55)$ & & $.153(1.44)$ \\
\hline Target & & $.167(1.41)$ & & $-.230(1.51)$ & & $-.016(.14)$ \\
\hline Jstress & & $-.039(.66)$ & & $-.246(3.14)^{* * *}$ & & $-.148(2.75)^{* * *}$ \\
\hline Whours & & $.002(.44)$ & & $-.011(1.96)^{* *}$ & & $-.003(.64)$ \\
\hline Longhr & & $-.009(.07)$ & & $-.016(.12)$ & & $.007(.07)$ \\
\hline Satcowk & & $-.011(.18)$ & & $.070(1.07)$ & & $.039(.73)$ \\
\hline Satprom & & $-.013(.28)$ & & $.115(2.24)^{* *}$ & & $.068(1.57)$ \\
\hline Inreward & & $-.021(1.97)^{* *}$ & & $.026(2.04)^{* *}$ & & $-.003(.32)$ \\
\hline Constant & $.409(1.16)$ & $.885(1.60)^{*}$ & .550 (1.29) & $.306(.48)$ & $-.048(.15)$ & $-.132(.26)$ \\
\hline
\end{tabular}




\begin{tabular}{l|l|l|l|l|l|l}
\hline Sample size & 1299 & 1065 & 1099 & 927 & 1309 & 1074 \\
\hline Pseudo $\mathrm{R}^{2}$ & .098 & .108 & .119 & .200 & .074 & .092 \\
\hline
\end{tabular}

Note: The regression analyses also included all other individual characteristics variables (gender, age, tenure, and 7 educational and professional qualifications dummies), 6 occupational dummies and 11 industry dummies. Sample weights are used. 
Table 6. Ordered-probit Regression Results

\begin{tabular}{|c|c|c|c|c|}
\hline \multirow{3}{*}{$\begin{array}{l}\text { Independent } \\
\text { Variables }\end{array}$} & \multicolumn{4}{|c|}{ Dependent Variable } \\
\hline & \multicolumn{2}{|c|}{$\begin{array}{l}\text { Kcomit_ff (if Comit_ff }=1 \text { ) } \\
\text { (HPM individual measures) }\end{array}$} & \multicolumn{2}{|c|}{$\begin{array}{c}\text { Kcomit_ff (if Comit=1) } \\
\text { (HPM index measure) }\end{array}$} \\
\hline & Model I & Model II & Model III & Model IV \\
\hline \multicolumn{5}{|c|}{ 1. Family status variables } \\
\hline Ms_child & $-.103(.72)$ & $-.055(.36)$ & $-.094(.65)$ & $-.047(.31)$ \\
\hline Ms_nchild & $.329(1.97)^{* *}$ & $.269(1.42)$ & $.269(1.69)^{*}$ & $.220(1.20)$ \\
\hline Md_child & $-.099(.97)$ & $-.159(1.44)$ & $-.085(.82)$ & $-.145(1.31)$ \\
\hline Md_nchild & $.045(.47)$ & $-.080(.75)$ & $.032(.34)$ & $-.090(.85)$ \\
\hline Nm_child & $-.135(1.00)$ & $-.261(1.83)^{*}$ & $-.126(.92)$ & $-.277(1.94)^{*}$ \\
\hline Regcare & $-.032(.24)$ & $-.071(.48)$ & $-.058(.45)$ & $-.081(.55)$ \\
\hline \multicolumn{5}{|c|}{ 2. High performance management measures } \\
\hline Ownwork & $.135(1.60)$ & $.052(.54)$ & & \\
\hline Owntask & $.235(2.91)^{* * *}$ & $.213(2.34)^{* *}$ & & \\
\hline Iinvdewk & $.440(5.61)^{* * *}$ & $.387(4.45)^{* * *}$ & & \\
\hline Sugg_sch & $-.008(.10)$ & $-.018(.20)$ & & \\
\hline Inf_meet & $-.131(1.12)$ & $-.173(1.37)$ & & \\
\hline Exp_meet & $.292(2.64)^{* * *}$ & $.272(2.28)^{* *}$ & & \\
\hline Groupm & $-.119(1.34)$ & $-.075(.77)$ & & \\
\hline Train & $.015(.20)$ & $.006(.08)$ & & \\
\hline Hpindex & & & $.401(5.45)^{* * *}$ & $.307(3.57)^{* * *}$ \\
\hline \multicolumn{5}{|c|}{ 3. Other job characteristics } \\
\hline Pjob & $.218(1.83)^{*}$ & .205 (1.58) & $.220(1.84)^{*}$ & $.175(1.35)$ \\
\hline Ptime & $.379(4.10)^{* * *}$ & $.298(2.49)^{* *}$ & $.408(4.40)^{* * *}$ & $.342(2.85)^{* * *}$ \\
\hline Union & $-.203(2.32)^{* *}$ & $-.185(1.98)^{* *}$ & $-.247(2.95)^{* * *}$ & $-.216(2.37)^{* *}$ \\
\hline Public & $-.037(.37)$ & $-.063(.56)$ & $-.037(.39)$ & $-.060(.54)$ \\
\hline Fsize1 & $-.008(.07)$ & $-.201(1.70)^{*}$ & $.033(.32)$ & $-.161(1.40)$ \\
\hline Fsize2 & $.037(.27)$ & $-.065(.42)$ & $.060(.45)$ & $-.036(.24)$ \\
\hline Fsize3 & $-.124(1.08)$ & $-.195(1.53)$ & $-.138(1.24)$ & $-.207(1.66)^{*}$ \\
\hline Pension & $.214(2.12)^{* *}$ & $.259(2.25)^{* *}$ & $.176(1.76)^{*}$ & $.226(1.94)^{*}$ \\
\hline Sickpay & $-.164(1.88)^{*}$ & $-.252(2.59)^{* * *}$ & $-.144(1.67)^{*}$ & $-.236(2.45)^{* *}$ \\
\hline Ppay & & $-.120(1.09)$ & & $-.095(.87)$ \\
\hline Pshare & & $.040(.31)$ & & $.011(0.08)$ \\
\hline Apprais & & $-.089(1.00)$ & & $-.082(.94)$ \\
\hline
\end{tabular}




\begin{tabular}{l|l|l|l|l}
\hline Target & & $-.167(1.82)^{*}$ & & $-.182(2.01)^{* *}$ \\
\hline Jstress & & $-.092(2.07)^{* *}$ & & $-.100(2.28)^{* *}$ \\
\hline Whours & & $-.003(.78)$ & & $-.002(.48)$ \\
\hline Longhr & & $-.119(1.51)$ & & $-.139(1.77)^{*}$ \\
\hline Satcowk & & $.086(1.72)^{*}$ & & $.100(2.06)^{* *}$ \\
\hline Satprom & & $.169(4.78)^{* * *}$ & & $.165(4.74)^{* * *}$ \\
\hline Inreward & & $.029(3.17)^{* * *}$ & & $.032(3.70)^{* * *}$ \\
\hline Sample size & 1103 & 931 & 1103 & 931 \\
\hline Pseudo $\mathrm{R}^{2}$ & .055 & .095 & .040 & .08 \\
\hline
\end{tabular}

Note: The regression analyses also included all other individual characteristics variables (gender, age, tenure, and 7 educational and professional qualifications dummies), 6 occupational dummies and 11 industry dummies. Sample weights are used. 


\section{References}

Barnett, R., N. Marshall and A. Sayer. 1992. "Positive-Spillover Effects from Job to Home: A Closer Look," Women and Health 19: 13 - 41.

Batt, Rosemary and Valcour, P. Monique. 2003. "Human Resource Practices as Predictors of Work-Family Outcomes and Employee Turnover," Industrial Relations 42: 189 - 220.

Berg, Peter, Kalleber, Arne and Appelbaum, Eileen. 2003. "Balancing Work and Family: The Role of High-Commitment Environments," Industrial and Labor Relations 42:168 - 88.

Blair-Loy, M. and A. S. Wharton. 2004. "Organizational Commitment and Constraints on Work-Family Policy Use: Corporate Flexibility Policies in a Global Firm," Sociological Perspectives 47: $243-67$.

Bosch, G. 1999. "Working Time: Tendencies and Emerging Issues," Labour Market Trends 112: $113-22$.

Brown, Michelle and John Heywood. 2005. "Performance Appraisal: Determinants and Change," British Journal of Industrial Relations, Forthcoming.

Budd, John and Karen Mumford. 2005. "Family-Friendly Work Practices in Britain: Availability and Perceived Accessibility," IZA Discussion Paper No. 1662, July.

Budd, John and Karen Mumford. 2004. "Trade Unions and Family Friendly Policies in Britain," Industrial and Labor Relations Review 57: 204 - 22.

Burud, Sandra and Marie Tumolo. 2004 Leveraging the New Human Capital: Adaptive Strategies, Results Achieved and Stories of Transformation, Palo Alto, CA: Davies-Black Publishers.

Cappelli, Peter and David Neumark, 2001. “Do “High-Performance” Work Practices Improve Establishment-Level Outcomes? Industrial and Labor Relations Review 57: 737-775. 
Castles, F. 2003. "The World Turned Upside Down: Below Replacement Fertility, Changing Preferences and Family-Friendly Public Policy in 21 OECD Countries," Journal of European Social Policy 13: $201-27$.

Coyle-Shapiro, Jackie and Ian Kessler, 2000. “Consequences of the Psychological Contract for the Employment Relationship: A Large Scale Survey”, Journal of Management Studies, 37: 903-930.

Dex, Shirley. 2003. Families and Work in the Twenty-First Century. York: Joseph Rowntree Foundation and Policy Press.

Drago, Robert, David Black and Mark Wooden. 2005. "The Existence and Persistence of Long Work Hours," IZA Discussion Paper No. 1720, August.

Drewianka, Scott. 2005. "A Theory of Optimal Commitment Intensity," Working Paper, Department of Economics, University of Wisconsin-Milwaukee.

Evans, J., Lippoldt, D. and Marianna, P. 2001. "Trends in Working Hours in OECD Countries," OECD Labour Market and Social Policy Occasional Papers (45).

Gallier, D., Michael White, M. Tomlinson and Y. Cheng.1998. Restructuring the Employment Relationship. Oxford: Oxford University Press.

Green, Francis. 2001. "It's Been a Hard Day's Night: The Concentration and Intensification of Work in Late Twentieth Century Britain," British Journal of industrial Relations 39: 53 80.

Goddard, J. 2001. "High-Performance and the Transformation of Work? The Implications of Alternative Work Practices for the Experience and Outcomes of Work," Industrial and Labor Relations Review 54: 776 - 805.

Guest, David, 1998. “Is the Psychological Contract Worth Taking Seriously?”, Journal of Organizational Behaviour, 19: 649-64. 
Guest David, Jonathan Michie, Neil Conway and Maura Sheehan, 2003. "Human Resource Management and Corporate Performance in the UK”, British Journal of Industrial Relations, 41: 291-314.

Heywood, John, W.S. Siebert and Xiangdong Wei. 2005. "The Implicit Costs and Benefits of Family Friendly Work Practices," IZA Discussion Paper No. 1581, May.

Heywood, John, W.S. Siebert and Xiangdong Wei. 2002. "Worker Sorting and Job Satisfaction: The Case of Union and Government Jobs," Industrial and Labor Relations Review 55: $596-609$.

Hochschild, Arlie. 1997. The Time Bind: When Work Becomes Home and Home Becomes Work. New York: Metropolitan Books.

Jovanovic, Boyan. 1979. "Firm Specific Capital and Turnover," Journal of Political Economy 87: $1246-60$.

Kirby E. and K. Krone. 2002. "The Policy Exists but You Can't Really Use it: Communication and the Structuration of Work-Family Policies," Journal of Applied Communication Research 30: 50 - 77.

MacInnes, John. 2005. "Work-Life Balance and the Demand for Reduction in Working hours: Evidence from the British Social Attitudes Survey," British Journal of Industrial Relations 43: $273-95$.

Marsden, David, 2004. “The 'Network Economy’ and Models of the Employment Contract”, British Journal of Industrial Relations 42: 659-84.

Maume, David and Marcia Bellas. 2001. "The 'Overworked American' or the 'Time Bind': Assessing Competing Explanations for Time Spent in Paid Labor," American Behavioral Scientist 44: 1137 - 56.

Maume, David and P. Houston. 2001. "Job Segregation and Gender Differences in Work-Family 
Spillover among White-Collar Workers, "Journal of Family and Economic Issues 22: 171 89.

Osterman, Paul. 1995. "Work-Family Programs and the Employment relationship," Administrative Science Quarterly 40: 681 - 700.

Ramsay, H., D. Scholarios and B. Harley, B. 2000. "Employees and High-Performance Work Systems: Testing Inside the Black Box," British Journal of Industrial Relations 38: 501 32.

Robinson, John and G.eoffrey Godbey. 1999. Time for Life: The Surprising Ways Americans Use Their Time, $2^{\text {nd }}$ ed. University Park PA: Pennsylvania State University Press.

Palomba, R. 2003. Reconciliation of Work and Family. European Population Papers. Strasbourg:

Council of Europe.

Voydanoff, Patricia. 1988. "Work Role Characteristics, Family Structure Demands, and Work-Family Conflict," Journal of Marriage and the Family 50: 749 - 61.

Walling, Annette. 2005. "Families and Work" Labour Market Trends 113(July): 275 - 83.

Walton Richard, 1985. "From Control to Commitment in the Workplace”, Harvard Business Review, March-April: 77-84.

White, Michael, Stephen Hill and Patrick McGovern, Colin Mills and Deborah Smeaton. 2003. “ ‘High Performance’ Management Practices, Working Hours and Work-Life Balance”, British Journal of Industrial Relations 41: 175 - 95.

Wood, Stephen. 1999. "Family-Friendly Management: Testing the Various Perspectives," National Institute Economic Review 168: 99 - 116. 


\section{Endnotes}

${ }^{1}$ For the same reason they may not choose jobs offering extensive family friendly work practices. Heywood et al (2005) show that such jobs are associated with a significant and large negative compensating differential. Holding all else constant, family-friendly jobs pay less.

${ }^{2}$ In addition to high performance workplaces, other terms used to describe the same phenomenon include high commitment management, high performance work systems and high performance work organizations.

${ }^{3}$ The specific measures are themselves the aggregation of several underlying indicators. Thus, the opportunity to participate variable is an index built up from indicators of the worker's ability to direct his or her own activities (autonomy), the presence of teams, and the nature of communication within the firm.

${ }^{4}$ We highlight Hochschild's view while recognizing the considerable debate over its generality. See for instance Maume and Bellas (2001) who take issue with her sample of firms and the role of HPWs in providing a "haven" from home.

${ }^{5}$ In other words, there is a kind of "quasi-gift exchange" (Marsden, 2004) in the HPW to encourage above-average performance

${ }^{6}$ Throughout our analyses, we also use the weights provided with the survey data, which take account of differing selection probabilities with respect to household size, age, sex, contractual status (full-time and part-time) and socio-economic group, using the 2000 Labor Force Survey as a benchmark (see White et al., 2000).

${ }^{7}$ In addition to the specifications shown, we also removed the industry and occupational dummies from the series of estimates and also further curtailed the controls by reducing the individual and workplace characteristics. All estimates confirmed the basic role of HPWs in increasing the probability of fulfilling the commitment and so increasing the probability of both making and keeping the commitment. These experiments are available from the authors. 